\title{
The Early Childhood Education Teachers' Needs of Being Able to Teach English Well
}

\author{
Bambang Harmanto', Heri Wijayanto ${ }^{2}$, Ida Yeni Rahmawati ${ }^{3}$, M. Fadlillah $^{3 凶}$ \\ Pendidikan Bahasa Inggris, Universitas Muhammadiyah Ponorogo, Indonesia(1), Manajemen, \\ Universitas Muhammadiyah Ponorogo, Indonesia(2), Pendidikan Guru Pendidikan Anak \\ Usia Dini, Universitas Muhammadiyah Ponorogo, Indonesia(3) \\ DOI: $\underline{10.31004 / \text { obsesi.v6i3.1256 }}$
}

\begin{abstract}
English should be introduced and taught to early childhood in a fun way. Early childhood education teachers are required to have the ability to teach English in a good and fun way. The purpose of this study is to explore the needs of being able to teach English well for the early childhood education teacher (ECET). The survey technique was conducted with 56 respondents from the ECE teachers. The survey was conducted via google form with 15 questions. The result showed that $55 \%$ of the respondents gave priority of developing instructional media and materials in the expected training. Meanwhile as many as 33\% of expected training was emphasized on teaching technique as the first prominent. The only $12 \%$ who considered motivation training was very principle. All trainings they were expecting the needs of designing training concept such as duration, facilitator, methodology, material, media, and setting of places were fully considered.
\end{abstract}

Keywords: early childhood education; ecet; teaching english; young learner.

\begin{abstract}
Abstrak
Bahasa Inggris harus diperkenalkan dan diajarkan kepada anak usia dini dengan cara yang menyenangkan. Guru PAUD dituntut memiliki kemampuan mengajar bahasa Inggris dengan cara yang baik dan menyenangkan. Tujuan dari penelitian ini adalah untuk menggali kebutuhan untuk dapat mengajar bahasa Inggris dengan baik bagi guru PAUD (ECET). Penelitian ini dilakukan melalui teknik survei dengan melibatkan 56 responden dari para guru PAUD. Survei dilakukan melalui formulir google dengan 15 pertanyaan. Hasil penelitian menunjukkan bahwa 55\% responden mengutamakan pengembangan media dan materi pembelajaran dalam pelatihan yang diharapkan. Sedangkan sebanyak 33\% diharapkan pelatihan ditekankan pada teknik mengajar sebagai unggulan pertama. Hanya $12 \%$ yang menganggap pelatihan motivasi sangat prinsip. Semua pelatihan yang mereka harapkan untuk kebutuhan perancangan konsep pelatihan seperti durasi, fasilitator, metodologi, materi, media, dan pengaturan tempat dipertimbangkan sepenuhnya.
\end{abstract}

Kata Kunci: pendidikan anak usia dini; ecet; mengajar bahasa inggris; anak usia dini.

Copyright (c) 2021 Bambang Harmanto, et al.

$\triangle$ Corresponding author:

Email Address : fadly_ok@yahoo.co.id (Ponorogo, Indonesia)

Received 9 April 2021, Accepted 19 April 2021, Published 17 September 2021 


\section{INTRODUCTION}

The policy of Indonesian government to introduce English formally to the early childhood education (ECE) students was still not stipulated yet. English becomes a compulsory subject for the students who have been in Junior high school level. In the context of Indonesian basic education, some researchers reported the imbalance between the results and the process of learning English. The value and outcome of competence were supposed to be far from satisfying, especially with the abolition of English lessons in elementary schools. The English lesson in Indonesia will merely become extracurricular activity thus students can choose whether they want to learn English or not. Therefore, when English was enforced to teach in ECE might be an institutional consideration. The English teaching in ECE finally is done as an additional subject which fully rely on the school management readiness as a part of parents' wants and expectations. Parents in general still want their children are equipped with English early. Children will have the chance and opportunity to take part into the global stage. They expected their children are able to adjust and respond to new globalization challenges properly. Argues that when young learners are able to speak another language it provides several advantages (Bialystok, 2018). One of them is mental flexibility which means the ability to see a problem from different perspectives. Children can also increase their self awareness. Marsh \& Langé, (2000) also stated that by using different languages even if it is not used much or used modestly can yield a positive effect on childrens' way of thinking. They will be able to see phenomenon from different point of views the way they use different languages. It will have a very interesting outcome on their ability to think and understand about things. Again, that in supporting their children efforts to have an ability to meet the globalization needs, mastery of English becomes significant. Due to the demand of mastering English there are so many countries having English as their foreign language in addition of their first language. It can be taken into account that English is vital for any country wishes to compete with other nations globally. As stated by (Peck et al., 1993) , (Bodapati, 2016), English is important in commmunication accross nation and of course this language has a great benefit for Indonesian to master. It has a long way of history as why English is regarded as the most prized posession in language mastery. The English language is used in international affairs such as international trades. It is the language of Internet, English is also the leading language of science and technology and major education. We cannot deny that globalization speed up the process of spreading English accross nations. It is expected that English language yield very high demand in every country. To fulfill their demands, teachers tried to teach their children English as far as they know. They know that they cannot serve them satisfactorily because they were not in linearly educational background. To get optimum learning result, there must be a great demand for specialized language teacher, since teaching to young learners requires special skill, competence, and motivation (Camlibel-Acar, 2016) Therefore, professional teachers are needed to support students' attitude who were mostly positive toward English. According to Asmali (2017) they will fully engage the class when their favorite activities like singing songs and playing games are available there for building their intrinsic motivation. In building a good education system the involvement from all parties are also compulsory (Johan \& Harlan, 2014).

Dealing with the early childhood education teacher (ECET) education qualification, it was found that as many as 58\% respondents hold bachelor degree on ECE. Meanwhile $42 \%$ of them were just graduated from senior high school (Harmanto, 2019). It was very clear they were not formally prepared to teach English. Another finding was addressed by Copland et al. (2014) who revealed that many challenges among them were more localized found in the process such as constructing appropriate curriculum, developing teachers' English competence, choosing and using proper media and method in the classroom. They argued that to gain the maximum exposure they must focus more on finding solution of the challenges they have identified than introducing to general approaches to English language teaching (Mustafa et al., 2018). In addition, (Nguyen, 2018) emphasized that beyond the locus of 
classroom practice, the age-appropriate pedagogy, the use of English in a creative way to realpractice helps the ECET's awareness of challenges and rewards of their work, meaning that the competent teachers are really needed to make the learning challenges done. The lack of helpful context, complex syntax, and technical vocabulary in content area reading add to the difficulties of ELLs in terms of comprehension (Ontario Ministry of Education, 2007). Teaching english to young learners are intended for one goal. It is to introduce them to the English language and hence exposing them the language since early time. This statement is supported by the fact that there are many benefits as why we need to make children learn English as early as possible. (Oyama, 1976) argues that before childrens reach puberty they have higher possibility to acquire native-like proficiency in a language they are learning. This thought is usually accepted by adults by saying that children could "pick up" a language easily. Moreover, (Marinova-Todd et al., 2000) concluded that young learners are the best and efficient learners in language. This is because they have already mastered their native language and they can also learn second language. To add more reason. Curtain \& Pesola Dahlberg (2000) state that if children learning journey begins in early time it can provide them more practice and as a result can give them more experience and this will lead to greater fluency in the language they are learning.

Looking at the above fact, the parents' expectation and the ECET's English teaching capacity still seems to be unbalanced. The benefits of early language learning can be achieved if the condition such as trained teachers is in place. Therefore; this paper would like to describe the result of exploring their needs for being able to introduce an English language well for their students. The output of the research is expected to leads the authors to design theoretical and practical concepts of trainings which are able to equip This idea in theoretical concepts will equip pre- and in-service ECE teacher with competence and knowledge about innovation, and they are expected to be capable of implementing such innovative ideas into classroom practice (Wang \& Cheng, 2005) . This guide should be a starting point for ECE teacher to expand on what they already know about the needs and the belief of their preschool English learners. Careful consideration of the beliefs will help preschool teachers focus on each child's experiences and circumstances as that child begins the journey toward the acquisition of academic English. Familiarity with these beliefs will also help teachers implement the information, principles, and practices presented in this guide (Sacramento, 2009) This paper also discusses about the children who learn a foreign language, in this context English. (Williams, 2002) stated that teachers should not compare children to adults or teenagers. Teaching children has different approaches and methods and of course the earlier we introduce English to the children the better they can master the language. in her book He argues that the difference of teaching children and adolescent are immensely obvious. Children still have no fear and self conscious in the learning processes and that means they do not afraid of making mistakes. Mistakes are usually scary and embarassing for us adults but they are very brave to speak up their minds. They are also tend to communicate with nativelike accent since they learn English intiutively and by asscociation through trials and errors rather by using grammar, drills, or discourse methods. The upside of teaching English to young learners are also stated by Piaget Children are fast in capturing and processing everything in the world that surrounds them. This as a result can influence their mental and language development. They are active learners which means that they solve problems by taking action. That is why children tend to be curious with virtually everything going on around them and they want to find the answers as soon as possible. Meanwhile Vygotsky views childrens' development and learning are supported through social context. People areound children such as parents and teachers. Learning about how to do and think something are both helped by interacting with an adult and in this case is teachers and parents. In teaching languages to young learners, it is also advisable for teachers to learn about childrens' level of understanding. Childrens are curious and they love to find out new things but they also tend to imitate others. in this regard in teaching childrens new language we should check 
whether they understand the languages or just mouthing what teachers say to them. (Macaulay \& Bailey, 1993); Anderson \& Lynch (1988) stated that children's want to please their teachers. The worst part is that they may continue following teachers activities even if they do not understand. They may carry on to do classroom activities without understanding of what they are doing. As stated above it is often to see that pupils in the classroom imitating the sentences in the text book as the teachers say and they seem to learn the activity but in reality they learn and understand nothing. To combat this problem Gilzow (2002) suggest that the effective young learners' program should use technology appropriately ans it also should be provided professional development. Nikolov \& Curtain (2000) stated the following characteristic of effective young learners language program such as programs which focuses on meaning; integrating language instruction with mainstream curriculum; Use task-based and content-based approaches; set realistic learning expectations and assessment and encourages learner autonomy.

\section{METHODOLOGY}

The design used in this study is a survey technique on finding ECE teachers' need to improve their teaching English quality for their children. The survey techniques which are given to the respondents was associated with online questionnaire. The survey was conducted via google form with 15 questions. The questions were related to the respondents' preferences to introduction English at early-age. Informal interview was also conducted to the board of kindergarten teacher association.

The close questioner was used to collect the data. The result will be used as ways to be able to design, analyze and operate a teacher capacity building system. In other words, one of the things used in this research is to do modeling. it is intended to make a model of the system. The model is very useful to show how a system works. The developed model will be adapted to the need to reach the capacity of ECE teachers in introducing English early. The design of this research can be seen in Figure 1.

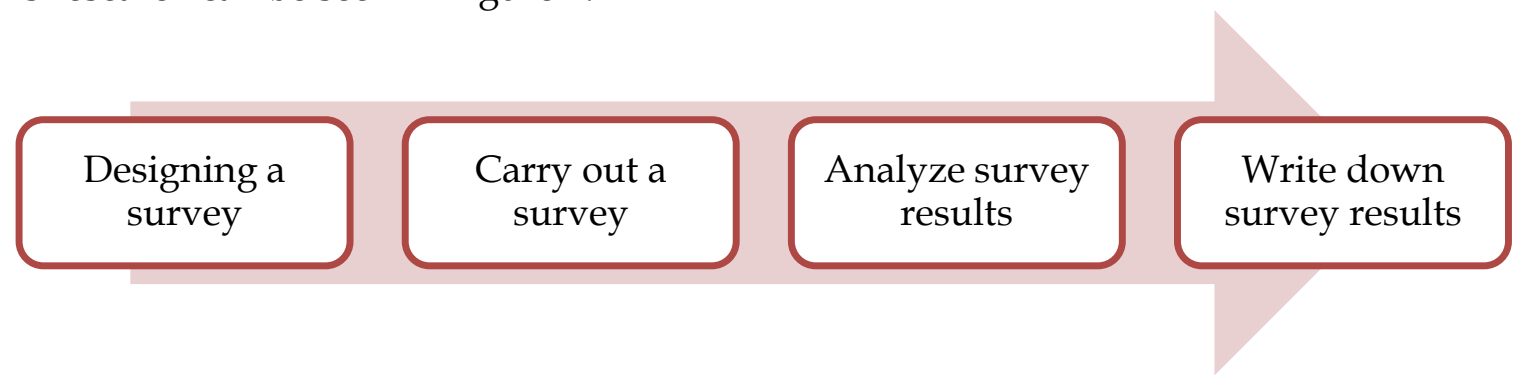

Figure 1. Survey research design

The data which were obtained from ECE teachers are spread in Ponorogo and other regions in Indonesia which involved 56 respondents as primary data. The respondents were taken randomly who has represented the population of ECET in Ponorogo. The data obtained from this research were information data from the data source in the form of responses. The results of this study were descriptively analyzed in the form of percentage. The result of analysis was used to find the configurations of the expected model by the author for conducting a further program in cultivating English to the ECET.

\section{RESULTS AND DISCUSSION}

The focus of the questions was about asking the types of activities the ECE teachers could suggest when they did not yet have the desired English teaching capacity. The finding showed that $55 \%$ of the respondents gave priority of developing instructional media and materials. Meanwhile as many as $33 \%$ of expected teaching technique as the first prominent, there were only $12 \%$ of people who considered motivation training was very principles. In their opinions, the expected training programs were related to the aspects of English syllabus 
for teaching young learners, the availability of EYL book, and motivation. From these activities, it was expected to help them employ appropriate teaching techniques, select appropriate instructional materials and media, avoid making serious grammatical mistakes and inappropriate pronunciation. It was linier with (Camlibel-Acar, 2016) has found that almost all of the prospective teachers he observed highlighted the benefits and usefulness of supporting the course with real classroom experiences: "I think we can learn how we can be teachers in classrooms, while we are living in the classroom atmosphere. We learn lots of things in our universities but we can achieve to be a good teacher by seeing a good teacher. In short words, the figure 2 clearly explained that most respondents prefer to learn about teaching technique in the training. The lesser percentage is about teaching technique training and the least is the motivation training.

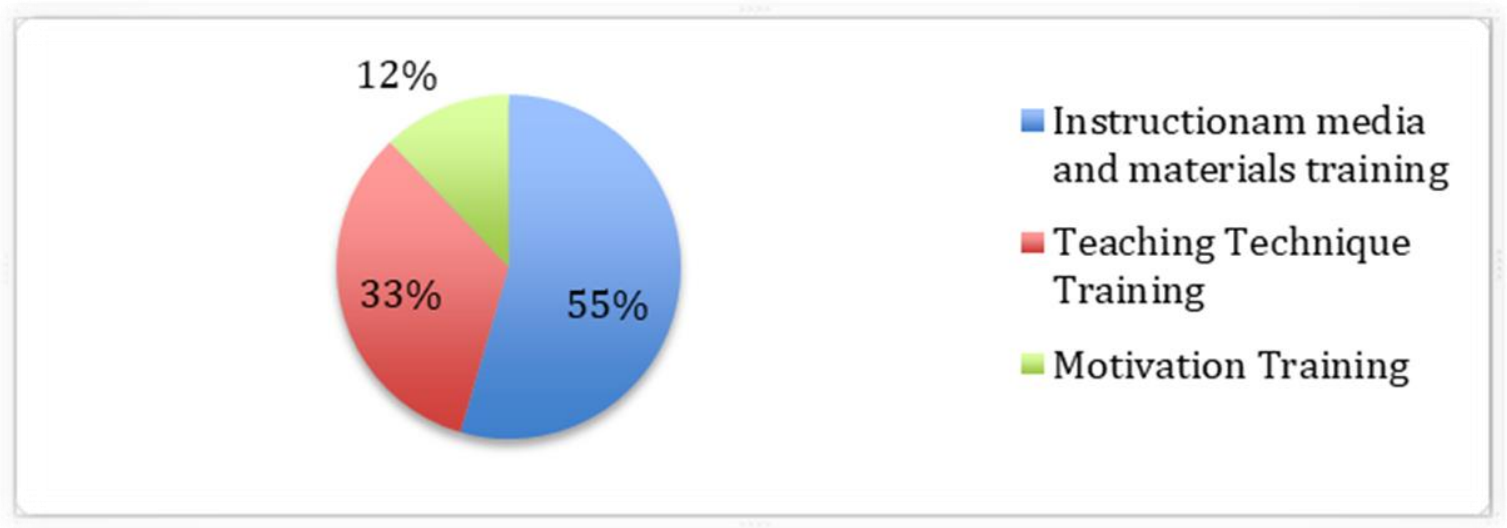

Figure 2. The Types of Expected Training

In practice, the recommendation of the survey led the researcher to construct the possible design of model for ECET capacity building program in introduction children with English. The attempt is arranged based on the level of importance through workshop and training activities. The distribution of activities starts from training of building ECET motivation to understand the reason of introducing English; training of joyful teaching strategies for the English to young learners, and training to develop instructional media and material for English to young learners including vocabulary, grammar, and pronunciation.

\section{Building Motivation Training}

This model is designed to ensure the teacher about language attitude and perception. The writer assumes that by having good language attitude and perception toward English will influence on the way of they teach. In other words, the model is intended to build the teachers' interest on the English world. It is important to note that if they have positive attitude and perception, they are willing to devote their teaching optimally. It can also allow them to perceive the task as enjoyable and meaningful experience. They will become motivated teachers who can create a successful output. Motivation is also crucial to keep them going over a long period of time. Therefore; they need to understand that their belief system on how they perceive teaching process inside the classroom could impact the output from the children (Qbeita, 2011). The following figures are information data describing ECET expectation on training of building motivation.

Seeing the figure 3, it seems that the respondent mostly wanted the training of motivation to be conducted between $1-2$ days. There were only 11 respondents who wanted the training to be more than two days. In means that the need to understand the importance of English started to learn earlier is sufficiently given at least one day session. 
DOI: 10.31004/obsesi.v6i3.1256

From the figure 4 above, most respondents chose motivator to be the trainer in the motivation training program. Meanwhile the rest of respondents chose psychology expert and education expert as the facilitator. It proved clearly that they needed the trainers who are competent in motivating them to realize the importance learning English earlier. The goal of motivation training is to give teachers knowledge so they can teach and nurture children to learn English. Motivation can be categorized into two types: intrinsic and extrinsic. Intrinsic motivation is a drive that comes from within a person. People are intrinsically motivated when they enjoy doing an activity.Extrinsic motivation is a drive that comes from outside of a person. People are extrinsically motivated when they want to gain a reward (like a prize or a good grade) or avoid a punishment. Generally, when someone already has intrinsic motivation, rewarding them can actually decrease their intrinsic motivation, making them less interested in the activity and therefore decreasing their performance.However, when someone isn't interested in a subject-meaning they have no intrinsic motivation to learn about itgiving rewards can get them to participate in the activity, which might then spark some intrinsic motivation within them. Extrinsic motivation can lead to intrinsic motivation. That's why your students will perform best when you focus on motivating them intrinsically rather than extrinsically. In other words, encourage their already present desire to learn rather than tempting them to learn with external rewards.

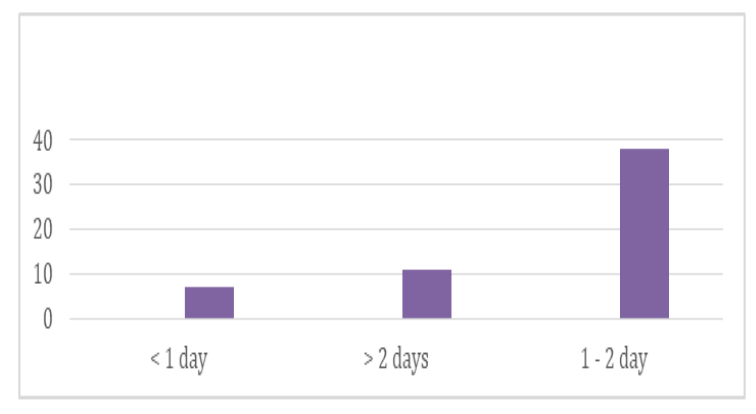

Figure 3. The Time Needed to Motivation Training

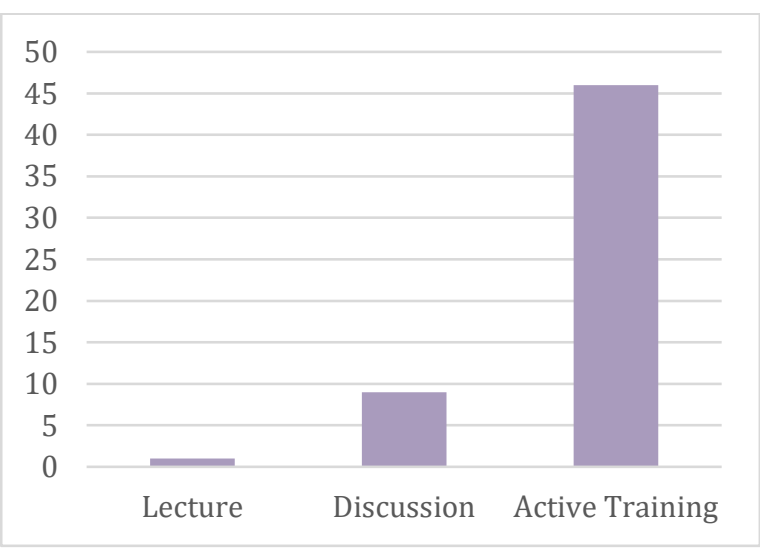

Figure 5. The Method of Motivation Training

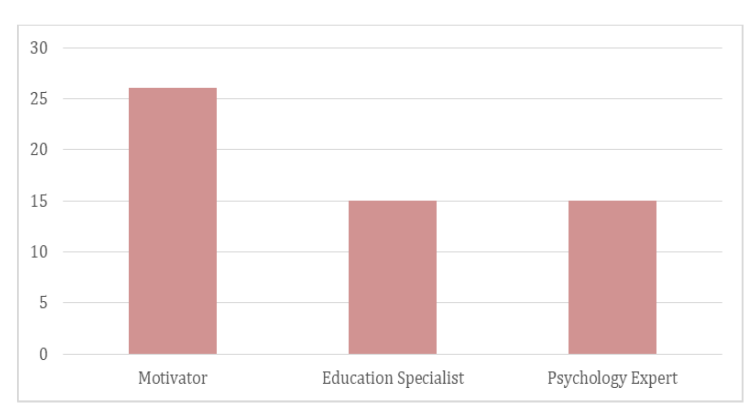

Figure 4. The Ideal Facilitator for Motivation training

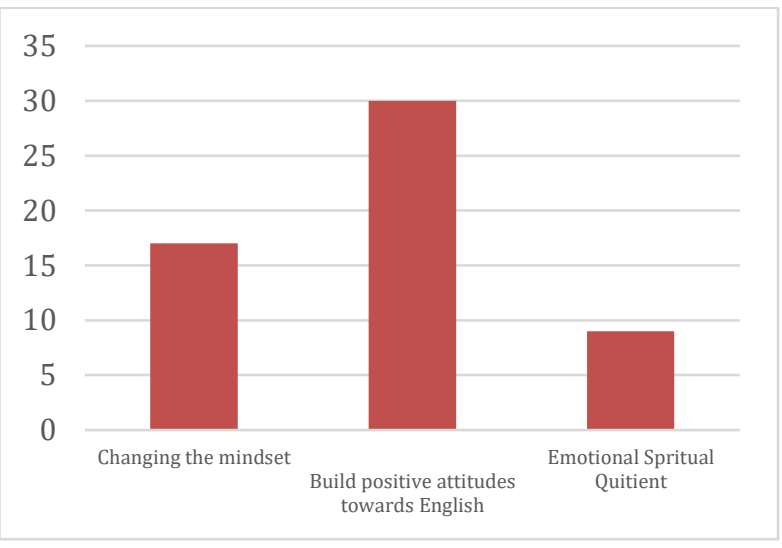

Figure 6. The Material for motivation training

Based on the figure 5, most respondents chose active training to be conducted in the training. The rest chose discussion and lecture. It was very realistic that they preferred to be trained in the practical ways instead of passive activities in the forms merely theoretical driven. They wanted to fully engage in the training for better absorption. 
In the figure 6, "building positive attitude towards English language was chosen by the majority of respondents". The least favorable material for motivation training was "ESQ". The fact showed that they need to look upon the English horizon to build their positive attitude toward English. It will help them easy acquire a confidence to teach their students.

Regarding to the place to conduct the training as illustrated in figure 7 , most respondents chose to have the training both outdoor and indoor. It was very reasonable to say that they wanted to have a mix training atmosphere which can be applicable in practicing the teaching method conductively. Outdoor spaces are the best play environments for children. These areas offer opportunities that are not found in indoor spaces and physical environment contributes to children's learning with owned affordances (Acar, 2014).

\section{Joyful Teaching Strategies on TEYL}

This model serves a teaching methodology class focused specifically on English to young learners. An educator who understands the theory and practice of teaching English to young learners is able to help learners navigate the processes of classroom learning activities to create a fun and positive environment. According to (W. L. Sutrisno, 2019), teaching English to young learners can be either detrimental or beneficial, depending on who is teaching, what is given and how it is administered. He underlines those unskilled teachers who lack training may place young learners in a risky situation as young learners are complex beings who have subtle attitude and thus, need careful handling. Once teachers discourage learners from learning, they are creating traumatic feeling in the part of the learners. On the contrary, if they can facilitate learning, they will create a situation where young learners can enjoy learning. In conducting evaluation, teacher should provide appropriate assessment. For example, the assessment which was done by (Choi et al., 2019) provided empirical support for the benefits of using scaffolding for EL assessments in a standardized setting. The kindergarten teachers did not have the fluency or the confidence of native speakers, and, in fact, they modelled grammatical errors, even in repeating the simple sentences in the official lesson plans. They also did not model native speaker pronunciation, and the audio cassettes of songs that accompanied the textbooks were poorly recorded and hard to understand. (Al-Darwish, 2012). The following figures are information data describing ECET expectation on training of teaching strategies.

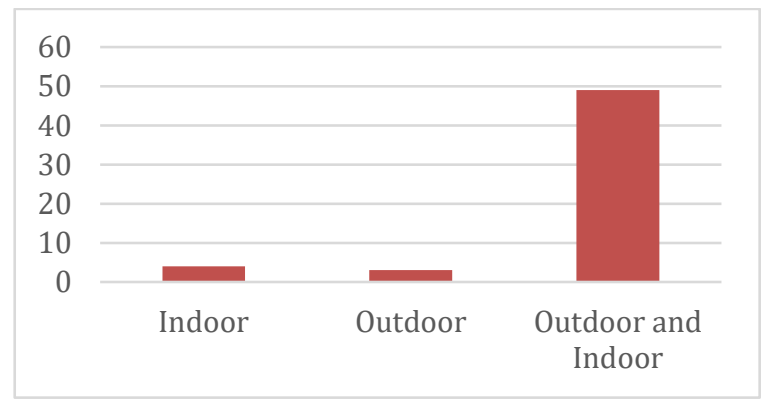

Figure 7. The Proper place to set motivation training

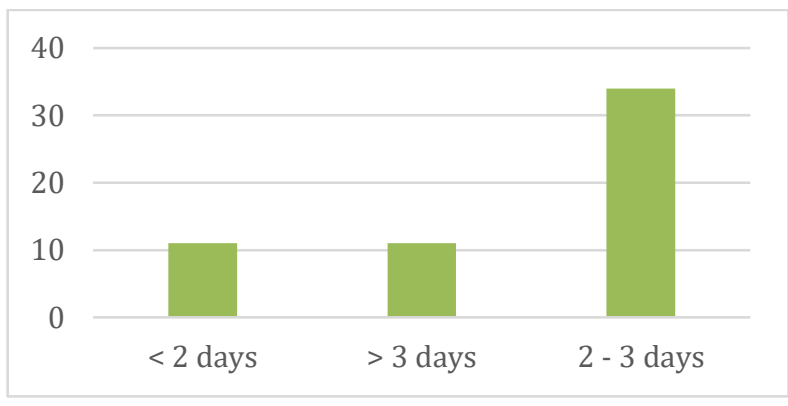

Figure 8. The Time needed to teaching technique training

Figure 8 showed that most respondents prefer the time of training between 2 to 3 days. Comparing with the building motivation training, the time to conduct the training of teaching strategies was longer. It might be logic because the trainer should practice a lot of methods and techniques in which they can follow and experience easly. They have to master many strategies that make their students enjoy the teaching.

Based on the retrieved data in figure 9, most respondents chose English Language Experts to train them in motivation training. It is, of course, very common view that the trainer they expected was those who are proficient and competent in English. They will get a more 
proper and correct English use rather than those whose no English background. Students who are learning English will be more confidence to join under a professional teacher.

From the data in figure 10, it showed that most respondents chose simulation as the technique in motivation training. The rest chose discussion and lecture. It was clearly that they wanted actively participated in the training. They wanted to directly practice what they got from the trainer. It can categorize it into learning by doing.

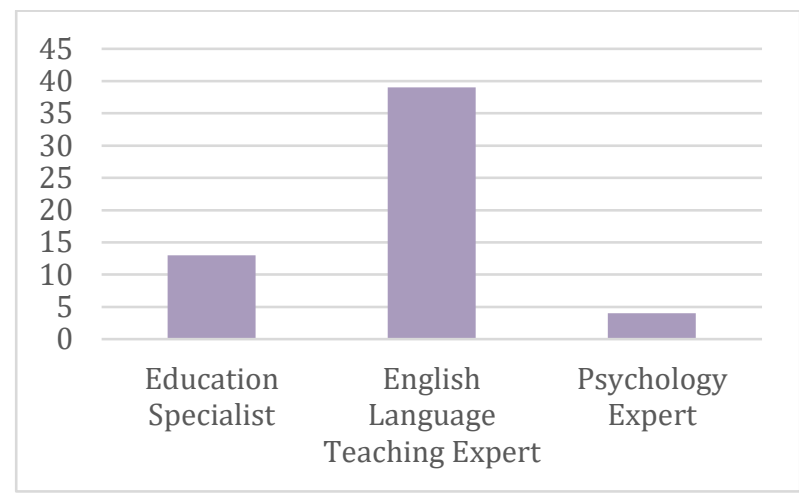

Figure 9. The Ideal facilitator for teaching technique training

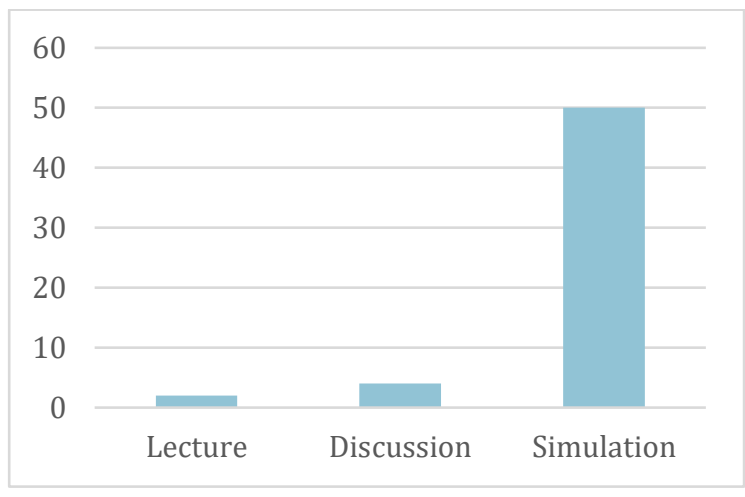

Figure 10. The Method of teaching technique training

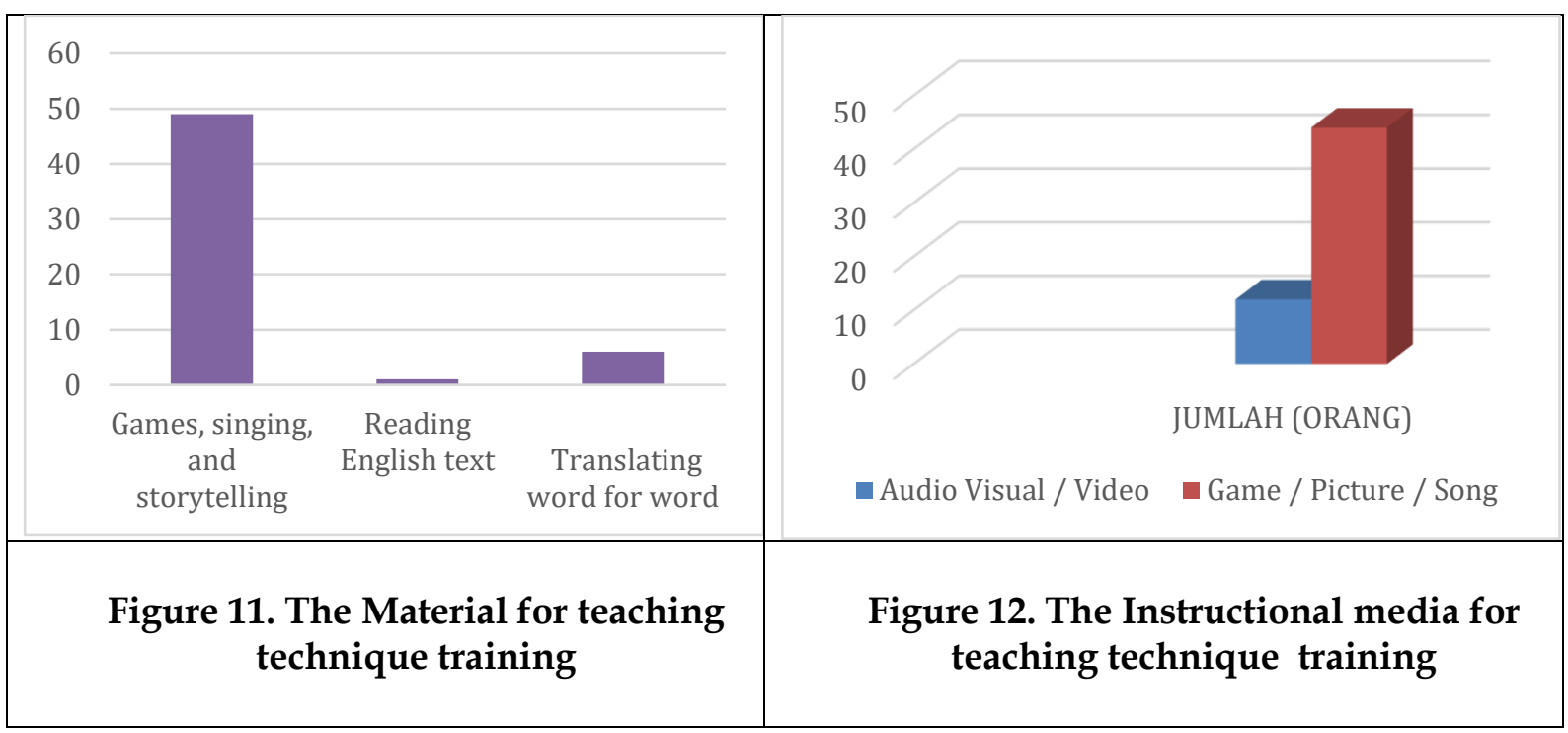

Looking at the figure 11, it was clearly that Games, Singing, and Storytelling are in the top choice of the respondents. Meanwhile "reading english text" is the least prefered choice of teaching material by respondents. It was quite right that they want to practice what their students like more. They will apply the approaches that are badly needed by the students' world and interest.

Based on the information described in figure 12 it was revealed that most respondents prefer to see motivation training instructional media in the form of games, figures, and songs. Related to the finding, it means that they needed the teaching aids that are suitable with the approaches they are using. They can imagine that their students will fully engage the teaching when the teacher presents English materials using interesting and motivating media. The students' intention and attention to learn English will be led easy by the teachers.

\section{Instructional media and English materials Development Training}

Teaching English to young learners, to a certain degree, is also affected by the choice of instructional materials and media. The wrongly chosen materials and media may put the 
learners in high risk of receiving the knowledge, which are not appropriate for their language development. This may block their path of learning, and inhibit the acquisition of the language. (V. L. P. Sutrisno \& Siswanto, 2016) added that teaching young learners requires teachers to collect and create their own materials, but at the same time, to have a number of handy items for the crafts activities they conduct in the classroom. Teachers should provide what it calls teacher's media to aid in the teaching process as well as make students engaged, such as: visual images, puppets, figure cards and other tools. If they find difficulties in providing the media the can seek for help (Aini, 2013). The following figures are information data describing ECET expectation on training of instructional media and English materials development.

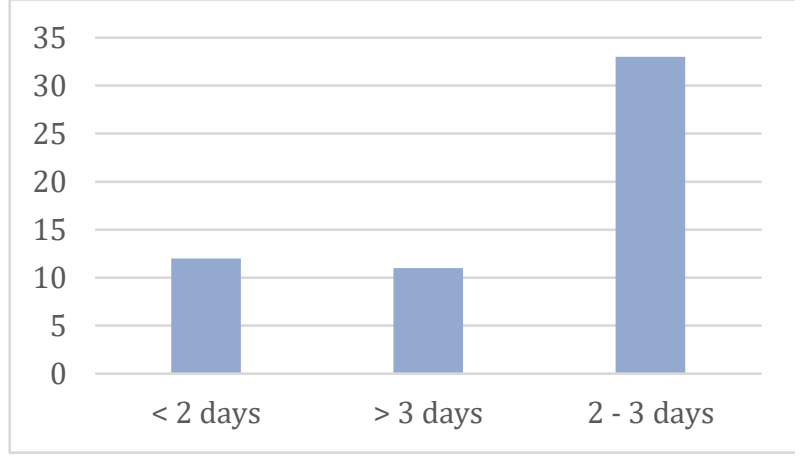

Figure 13. The Time needed to media and material development training

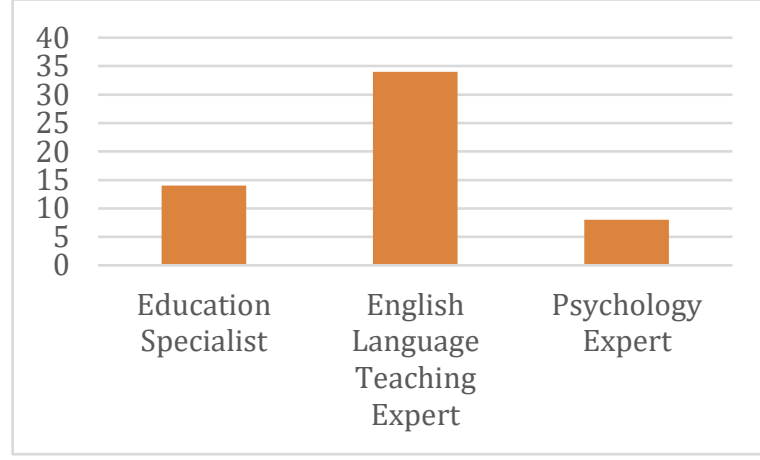

Figure 14. The Facilitator to media and material development training

According to the data in figure 13 above, the development training duration which are preferable for the respondents are between 2 to 3 days. Based on this data, the time allocation for conducting the training was the same as the training for teaching strategies. It was very clear that they need more time to arrange the material and teaching media for introducing English early. They wanted to have an ability to select the material and teaching media that are easily developed and contextually needed in their daily life. With appropriately material and media they can prepare, their students are expected to acquire English input joyfully and meaningfully.

Seeing the figure 14, it seems that the respondent mostly wanted English language expert as the facilitator of development training.

Figure 15 clearly described that the method which is preferable for most audiences based on the data above is experiential learning. It was quite understandable that they wanted to be trained in a real practice. They will be easy to reproduce the material they just learned with some adaptation. They will quickly remember when the trainer is showing and doing the material should be developed. They can directly observe and try to design the materials they want to develop.

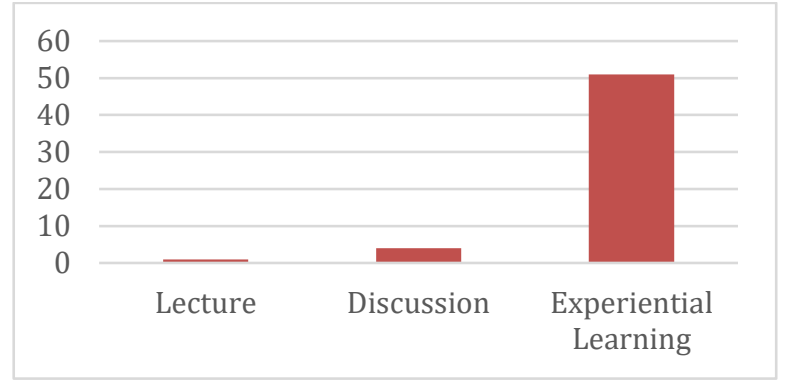

Figure 15. The Method to media and material development training

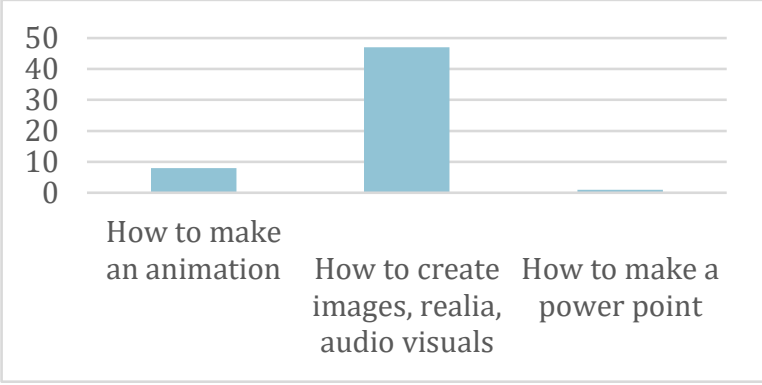

Figure 16. The Material to media and material development training 
DOI: 10.31004/obsesi.v6i3.1256

Upon receiving the data as in figure 16, it can be concluded that most respondents chose how to make figures, realia and audio visuals in the development training. Only small percentage of respondents chose "how to make powerpoint." It was clear that in terms of material for training, they preferred to be trained to the procedures of making material that are often used by the students in their daily teaching. The material they needed are almost naturally hand-made instead of electronic or computer-based materials. They might realize that their students are still in the concrete developing stage.

\section{CONCLUSIONS}

Introducing English to early childhood is very important. The teacher as a learning resource for children should be given training on learning English that is interesting and fun. Through various trainings teachers can introduce and teach English properly according to the characteristics of early childhood development. In addition, appropriate and varied English learning media is needed to make it easier to understand. For that, teachers must continue to learn and develop their abilities through various trainings.

\section{ACKNOWLEDGMENTS}

This paper is a part research project outcome which is planned to develop a system to build the ECE teachers' capacity in introducing English early. The author would like to thank everybody for their help with compiling the corpus, data, and information. The author also expresses gratitude to the Indonesian government especially the ministry of education and culture directorate of research and technology and higher education which has given him a financial support with the number of agreement 8/87/E3/ Ra.00/2020.

\section{REFERENCES}

Acar, H. (2014). Learning Environments for Children in Outdoor Spaces. Procedia - Social and Behavioral Sciences, 141, 846-853. https:// doi.org/10.1016/j.sbspro.2014.05.147

Aini, W. N. (2013). Instructional Media in Teaching english to young learners. Journal of English and Education, 1(June), 196-205.

Al-Darwish, S. (2012). Kindergarten Children and Language Learning: Missing Pillars for Language Acquisition. International Journal of Higher Education, 2(1), 44-52. https://doi.org/10.5430/ijhe.v2n1p44

Anderson, A., \& Lynch, T. (1988). Language Teaching. A Scheme for Teacher's Education.

Asmali, M. (2017). Young Learners' Attitudes and Motivation to Learn English. NovitasROYAL (Research on Youth and Language), 11(1), 53-68.

Bialystok, E. (2018). Bilingual education for young children: review of the effects and consequences. International Journal of Bilingual Education and Bilingualism. https:// doi.org/10.1080/13670050.2016.1203859

Bodapati, P. B. (2016). Impact of Globalization on English Language. 2(XXIII).

Camlibel-Acar, Z. (2016). Teaching English to Young Learners: Some Challenges Faced by Preservice Teachers. The Eurasia Proceedings of Educational \& Social Sciences, 5, 323-327.

Choi, I., Wolf, M. K., Pooler, E., Sova, L., \& Faulkner-Bond, M. (2019). Investigating the Benefits of Scaffolding in Assessments of Young English Learners: A Case for Scaffolded Retell Tasks. Language Assessment Quarterly, 16(2), 161-179. https://doi.org/10.1080/15434303.2019.1619180

Copland, F., Garton, S., \& Burns, A. (2014). Challenges in Teaching English to Young Learners: Global Perspectives and Local Realities. TESOL Quarterly, 48(4), 738-762. https://doi.org/10.1002/tesq.148

Curtain, H., \& Pesola Dahlberg, C. A. (2000). Planning for Success: Common Pitfalls in the Planning of Early Foreign Language Programs. Eric Digest. ERIC Clearinghouse on Languages and Linguistics, 1-8. ERIC 
Donzelli, G. (2003). Lessons Learned. Model Early Foreign Language Programs. System, 31(1), 147-148. https:// doi.org/10.1016/S0346-251X(02)00083-0

Genesse, harley y. (2000). An Early Start: Young Learners and Modern Languages in Europe and Beyond. 252. https:// books.google.com/books?id=63DnlgYjCNsC\&pgis=1

Harmanto, B. (2019). Preserving The Uniqueness of English Teaching at Early Childhood Education. https:// doi.org/10.4108/eai.27-4-2019.2285319

Johan, R., \& Harlan, J. (2014). Education Nowadays. International Jounal of Educational Science and Research (IJESR), 4(5), 51-56.

Macaulay, R., \& Bailey, R. W. (1993). Images of English: A Cultural History of the Language. Language, 69(4), 789. https:// doi.org/10.2307/416887

Marinova-Todd, S. H., Marshall, D. B., \& Snow, C. E. (2000). Three Misconceptions about Age and L2 Learning. TESOL Quarterly, 34(1), 9. https:/ / doi.org/10.2307/3588095

Marsh, D. (2000). Using languages to learn and learning to use languages: An introduction to content and language integrated learning for parents and young people. 1-16. http://archive.ecml.at/mtp2/CLILmatrix/pdf/1UK.pdf

Mustafa, M. C., Ngajib, S. H., Isa, Z. M., Omar, A., Osman, Z., Ahmad, N. A., Arip, M. A. S. M., \& Amran, A. N. F. M. (2018). Early Childhood Teachers' Challenges in Using English to Interact with Young English Language Learners. International Journal of Academic Research in Business and Social Sciences, 8(6). https:// doi.org/10.6007/IJARBSS/v8-i6/4179

Nguyen, M. H. (2018). The underlife of the classroom. Journal of Classroom Interaction, 53(1), 52-70.

Ontario Ministry of Education. (2007). Supporting English language learners in kindergarten: A practical guide for Ontario educators. Reading Improvement, 44(1), 32-39. http://www.edu.gov.on.ca/eng/document/kindergarten/\%5Cnhttp://www.edu.g ov.on.ca/eng/document/kindergarten/kindergartenell.pdf

Oyama, S. (1976). A sensitive period for the acquisition of a nonnative phonological system. Journal of Psycholinguistic Research, 5(3), 261-283. https:// doi.org/10.1007/BF01067377

Peck, S., Scott, W. A., \& Ytreberg, L. H. (1993). Teaching English to Children. TESOL Quarterly, 27(2), 350. https:// doi.org/10.2307/3587163

Qbeita, A. (2011). Kindergarten Teachers' Beliefs about Teaching English in Jordan. An - Najah Univ. J. Res. (Humanities)., 25(5).

Sacramento. (2009). Preschool English Learners.

Sutrisno, V. L. P., \& Siswanto, B. T. (2016). Faktor-Faktor Yang Mempengaruhi Hasil Belajar Siswa Pada Pembelajaran Praktik Kelistrikan Otomotif Smk Di Kota Yogyakarta. Jurnal Pendidikan Vokasi, 6(1), 111. https://doi.org/10.21831/jpv.v6i1.8118

Sutrisno, W. L. (2019). Language Style Used By Eric Thomas In The Motivational Video "Wake Up Early \& Make It Happen": A Stylistic Study.

Wang, H., \& Cheng, L. (2005). The impact of curriculum innovation on the cultures of teaching. Asian EFL Journal, 7(4), 7-43.

Williams, M. (2002). Teaching Languages to Young Learners. L. Cameron. ELT Journal, 56(2), 201-203. https://doi.org/10.1093/elt/56.2.201 